\title{
Erratum to: Analysis of in vitro ADCC and clinical response to trastuzumab: possible relevance of FcyRIIIA/FcyRIIA gene polymorphisms and HER-2 expression levels on breast cancer cell lines
}

\author{
Silvia Boero ${ }^{1}$, Anna Morabito ${ }^{2}$, Barbara Banelli ${ }^{2}$ Barbara Cardinali ${ }^{3}$, Beatrice Dozin ${ }^{4}$, Gianluigi Lunardi ${ }^{5}$, \\ Patrizia Piccioli ${ }^{6}$, Sonia Lastraioli ${ }^{7}$, Roberta Carosio ${ }^{2}$, Sandra Salvi ${ }^{8}$, Alessia Levaggi ${ }^{3}$, Francesca Poggio ${ }^{9}$, \\ Alessia D'Alonzo ${ }^{3}$, Massimo Romani ${ }^{2}$, Lucia Del Mastro ${ }^{3}$, Alessandro Poggi ${ }^{1}$ and Maria Pia Pistillo ${ }^{2^{*}}$
}

\section{Erratum to: J Transl Med (2015) 13:324 DOI 10.1186/s12967-015-0680-0}

It has come the publisher's attention that the original version of this article [1] unfortunately contained an error. In Table 3, first column, the Fc $\gamma$ RIIA $131 \mathrm{H}>\mathrm{R}$ genotypes were incorrectly labelled. In particular, V/V should have read $H / H, V / F$ should have read $H / R$ and $F / F$ should have $\operatorname{read} R / R$. Please note that this correction does not change the genotype numerical values of FcyRIIA polymorphism. The correct Table 3 has been published as Table 1 in this Erratum.

Table 1 Genotypic and allelic frequencies of FcyRIIIA and FcyRIIA polymorphisms in breast cancer patients and healthy controls

\begin{tabular}{|c|c|c|c|c|c|c|c|c|c|}
\hline \multirow[t]{2}{*}{ Genotypes } & \multicolumn{3}{|l|}{$n(\%)$} & \multirow[t]{2}{*}{$P^{*}$} & \multirow[t]{2}{*}{ Alleles } & \multicolumn{3}{|c|}{$n$ (frequency) } & \multirow[t]{2}{*}{$P^{\circ}$} \\
\hline & $\begin{array}{l}\text { NEO } \\
(n=15)\end{array}$ & $\begin{array}{l}\text { MTS } \\
(n=10)\end{array}$ & $\begin{array}{l}\text { CTR } \\
(n=33)\end{array}$ & & & $\begin{array}{l}\text { NEO } \\
(2 n=30)\end{array}$ & $\begin{array}{l}\text { MTS } \\
(2 n=20)\end{array}$ & $\begin{array}{l}\text { CTR } \\
(2 n=66)\end{array}$ & \\
\hline FcyRIIIA 158V>F & & & & & FcyRIIIA & & & & \\
\hline V/V & $4(26.7)$ & $3(30.0)$ & $6(18.2)$ & 0.741 & V & $13(0.43)$ & $8(0.40)$ & $26(0.39)$ & 0.934 \\
\hline V/F & $5(33.3)$ & $2(20.0)$ & $14(42.4)$ & & $\mathrm{F}$ & $17(0.57)$ & $12(0.60)$ & $40(0.60)$ & \\
\hline$F / F$ & $6(40.0)$ & $5(50.0)$ & $13(39.4)$ & & & & & & \\
\hline HWE & $P=0.213$ & $P=0.065$ & $P=0.522$ & & & & & & \\
\hline FcyR\|IA $131 \mathrm{H}>\mathrm{R}$ & & & & & FçR RIIA 1 & & & & \\
\hline $\mathrm{H} / \mathrm{H}$ & $3(20.0)$ & $4(40.0)$ & $9(27.3)$ & 0.499 & $\mathrm{H}$ & $14(0.47)$ & $10(0.50)$ & $35(0.53)$ & 0.843 \\
\hline$H / R$ & $8(53.3)$ & $2(20.0)$ & $17(51.5)$ & & $\mathrm{R}$ & $16(0.53)$ & $10(0.50)$ & $31(0.47)$ & \\
\hline$R / R$ & $4(26.7)$ & $4(40.0)$ & $7(21.2)$ & & & & & & \\
\hline HWE & $P=0.782$ & $P=0.058$ & $P=0.845$ & & & & & & \\
\hline
\end{tabular}

Genotyping of FcyRIIIA 158V>F was performed by a newly developed PSQ method after pre-amplification of FcyRIIIA gene. Genotyping of FcyRIIA $131 \mathrm{H}>\mathrm{R}$ was performed by T-ARMS PCR and SBT. Conventionally, the $158 \mathrm{~V}>\mathrm{F}$ variant corresponds to the G $>\mathrm{T}$ SNP [i.e. guanine corresponding to valine (V) and thymine corresponding to phenylalanine $(F)$ and the $131 \mathrm{H}>\mathrm{R}$ SNP corresponds to the A>G SNP [i.e. adenine corresponding to histidine $(\mathrm{H})$ and guanine corresponding to arginine $(\mathrm{R})$ ]

Comparison of FcyR genotypic and allelic frequencies between patients and control subjects was estimated using the Pearson's $X^{2}$ test ( $P^{*}$ value) and the Fisher's test $\left(P^{\circ}\right.$ value), respectively. Statistical significance: $P<0.05$

NEO neoadjuvant, MTS metastatic, CTR controls, HWE Hardy-Weinberg equilibrium. HWE was tested by the Pearson's $X^{2}$ test $(P<0.05$ indicates lack of HWE)

*Correspondence: mariapia.pistillo@hsanmartino.it

${ }^{2}$ Unit of Tumor Epigenetics, IRCCS AOU San Martino-IST, Genoa, Italy

Full list of author information is available at the end of the article 


\section{Author details}

${ }^{1}$ Unit of Molecular Oncology and Angiogenesis, IRCCS AOU San Martino-IST, Genoa, Italy. ${ }^{2}$ Unit of Tumor Epigenetics, IRCCS AOU San Martino-IST, Genoa, Italy. ${ }^{3}$ Development of Innovative Therapies Unit, IRCCS AOU San Martino-IST, Genoa, Italy. ${ }^{4}$ Clinical Epidemiology Unit, IRCCS AOU San Martino-IST, Genoa, Italy. ${ }^{5}$ Medical Oncology Unit, Sacro Cuore Don Calabria Hospital, Negrar, Verona, Italy. ${ }^{6}$ Cellular Biology Unit, IRCCS AOU San Martino-IST, Genoa, Italy. ${ }^{7}$ Laboratory of Molecular Diagnostics, IRCCS AOU San Martino-IST, Genoa, Italy. ${ }^{8}$ Unit of Pathology, IRCCS AOU San Martino-IST, Genoa, Italy. ${ }^{9}$ Unit of Medical Oncology 2, IRCCS AOU San Martino-IST, Genoa, Italy.

The online version of the original article can be found under doi:10.1186/s12967-015-0680-0.

Published online: 22 January 2016

\section{Reference}

1. Boero S, Morabito A, Banelli B, Cardinali B, Dozin B, Lunardi G, Piccioli P, Lastraioli S, Carosio R, Salvi S, Levaggi A, Poggio F, D’Alonzo A, Romani M, Del Mastro L, Poggi A, Pistillo MP. Analysis of in vitroADCC and clinical response to trastuzumab:possible relevance of FcyRIIIA/FcyRIIA genepolymorphisms and HER-2 expression levelson breast cancer cell lines. J Transl Med. 2015;13:324.

\section{Submit your next manuscript to BioMed Central and we will help you at every step:}

- We accept pre-submission inquiries

- Our selector tool helps you to find the most relevant journal

- We provide round the clock customer support

- Convenient online submission

- Thorough peer review

- Inclusion in PubMed and all major indexing services

- Maximum visibility for your research

Submit your manuscript at www.biomedcentral.com/submit
() BioMed Central 